\title{
Electrochemical Inactivation of Proteolytic and Lipolytic Hide Bacteria
}

\author{
Meral Birbir ${ }^{1}$, Yasar Birbir ${ }^{2 *}$, Esin Yilmaz ${ }^{3}$, Pinar Caglayan ${ }^{1}$ \\ 1 Division Plant Diseases and Microbiology, Department of Biology, Faculty of Arts and Sciences, Marmara \\ University, Goztepe, Istanbul, Turkey. \\ 2 Department of Electric and Electronic Engineering, Faculty of Technology, Marmara University, Goztepe, \\ Istanbul, Turkey. \\ ${ }^{3}$ Institute of Pure and Applied Sciences, Marmara University, Goztepe, Istanbul, Turkey. \\ * Corresponding author. Email: ybirbir@hotmail.com.tr \\ Manuscript submitted June 12, 2016; accepted August 10, 2016. \\ doi: 10.17706/ijbbb.2016.6.4.121-129
}

\begin{abstract}
Proteolytic and lipolytic bacteria may be found in hide-soak liquors. These microorganisms may affect leather quality adversely and cause important economic losses. Therefore, we examined lethal effect of 1 A DC treatment implemented with 1.5 A AC on mixed culture of Gram-positive and Gram-negative hide bacteria in Nutrient Broth containing 3\% NaCl in this study. Proteolytic and lipolytic Gram-positive Bacillus lentus, Staphylococcus intermedius, Aerococcus viridans and Enterococcus avium, Gram-negative Enterobacter cloacae and Pseudomonas putida, which were isolated from hide soak liquor in our previous study, were used as test microorganisms in this study. $\log _{10}$ reduction factors of 1.40, 1.62, 2.00 and 2.10 belonging to the mixed culture were detected after first, second, third and fourth cycles of electric current treatments, respectively. This study results exhibited that the electric treatment was efficient in reducing the cell counts of microorganisms found in hide-soak liquors.
\end{abstract}

Key words: Direct electric current, alternating electric current, hide bacteria.

\section{Introduction}

Raw hides are very suitable environment for bacterial growth. Therefore, hides are commonly preserved with salt to inhibit microbial growth and hide destruction during storage and transportation. Soaking is the first tannery process that rehydrates hides and remove blood, manure, salt, globular proteins, and fats found in hide [1]. Soaking process is applied to hides into two stages as pre-soaking and main soaking. While pre-soaking process contains high concentration of salt, main soaking process may contain $3 \% \mathrm{NaCl}$ [2], [3].

Duration of main soaking may be between 1.5 and 24 hours and this duration may change according to preservation method applied to hides and tanneries in different countries [1]-[3].

Soak liquors contain high organic matter, fats, soluble proteins, globular proteins, manure, flesh, lime, soap and the other substances which may support growth of microorganisms [3], [4].

Soaked hides treated with antibacterial agents may contain bacteria, proteolytic and lipolytic bacteria in high numbers and these microorganisms may damage hides during soaking process. Berber and Birbir (2010) isolated $10^{5}-10^{8} \mathrm{CFU} / \mathrm{g}$ of bacteria from 34 soaked hides [2]. Total proteolytic bacterial and lipolytic counts were ranged from $10^{4}-10^{8} \mathrm{CFU} / \mathrm{g}$ in 34 soaked hides [2]. 
Although antimicrobial substance is added into the main soaking, different species of bacteria belonging to the genera Enterobacter, Pseudomonas, Enterococcus, Lactococcus, Aerococcus, Micrococcus, Kocuria, Staphylococcus and Vibrio were obtained from main soak liquor treated with antibacterial agent [5].

Hair-slip, grain damage, loose grain, reduced firmness, pitting holes, putrefaction marks on the grain may occur on soaked hides due to bacterial attack [3], [6], [7].

Anderson and Finkelstein (1919), Beattie and Lewis (1925) and Prescott (1927) applied electric current in milk to kill microorganisms [8]-[10]. They reported that electric current could be effectively used to sterilize milk. The inactivation of microorganisms via electric current in synthetic urine [11], water [12], salt solutions [13], on human skin [14], on the surface of catheters [15], in activated sludge and biofilms [16], in effluent seawater [17], recirculated brine [18], soak liquors [19], brine solution, seawater and river water [20]-[23], on beef surfaces [24], on chicken legs [25], in fresh orange juice [26] and on surgical stainless steel [27] were also stated. Moreover, Proteus mirabilis, Staphylococcus epidermidis, Klebsiella pneumoniae, Escherichia coli and Staphylococcus aureus on intravascular catheters were reduced by $10 \mathrm{~mA}$ direct electric current [28]. In the study of Borden et al (2004), it was stated that the biofilm formation was prevented via electric current treatment. In that research, $100 \mu \mathrm{A} / \mathrm{cm}^{2} \mathrm{DC}$ treatment for 2.5 hours detached 95\% of biofilm formed by Staphylococcus aureus and Staphylococcus epidermidis from the surgical stainless steel in the presence of $1 \mathrm{mM}$ potassium phosphate [27].

Electric current applications have preferred owing to its high efficiency, low cost and ease of application [19]. Electric current treatment was also used to kill bacteria in pre-soaking and main soak liquors in leather industry, Turkey [19].

Lethal effect of 1.5A DC applied together with 2A AC on the mixed culture of Enterobacter cloacae, Vibrio fluvialis, Pseudomonas luteola, Staphylococcus cohnii, Enterococcus faecium and Bacillus pumilus was examined in the liquid culture containing $2 \% \mathrm{NaCl}$ and organic substances by investigators [29].

In addition, the inactivation effect of both direct and alternating electric currents on moderately halophilic bacterial species such as Acinetobacter johnsonii was investigated by scientists [30].

Moreover, extermination effect of $2 \mathrm{~A}$ alternating electric current on extremely halophilic archaea, proteolytic extremely halophilic archaea and lipolytic extremely halophilic archaea isolated from Tuz Lake in Turkey was examined [31].

In another study related with leather industry, Birbir et al. (2015) investigated separately extermination effect of 2A DC, 1.5A DC, 2A AC, 1.5A AC on antibiotic resistant, proteolytic and lipolytic moderately halophilic strains of Chromohalobacter israelensis, Halomonas halmophila, Chromohalobacter canadensis, Staphylococcus nepalensis and Halomonas halodenitrificans isolated from salted skins [32].

To prevent bacterial attacks on hides during the soaking process, we examined the efficiency of 1A DC treatment implemented with $1.5 \mathrm{~A} \mathrm{AC}$ on mixed culture of proteolytic and lipolytic Gram-positive and Gram-negative bacteria found in hide soak liquors in this present study.

\section{Materials and Methods}

\subsection{Test Microorganisms}

Protease and lipase positive Gram-positive (Bacillus lentus, Staphylococcus intermedius, Aerococcus viridans and Enterococcus avium) and Gram-negative (Enterobacter cloacae and Pseudomonas putida) bacteria were selected as test microorganisms. These strains were isolated from soak liquors and identified using the API test kits in our previous studies (Biomèrieux, France) [5], [33].

\subsection{Preparation of the Test Bacteria}

Bacillus lentus, Aerococcus viridans, Enterobacter cloacae, Enterobacter avium, Pseudomonas putida and 
Staphylococcus intermedius were grown separately in Nutrient Broth containing $3 \% \mathrm{NaCl}$ at $37^{\circ} \mathrm{C}$ for $24 \mathrm{~h}$. After, each of these bacterial cultures was suspended separately in sterile saline solution to a final cell density of $10^{8} \mathrm{CFU} / \mathrm{mL}$. Mixed culture of these microorganisms was prepared from these saline solutions.

\subsection{Inactivation of Proteolytic and Lipolytic Bacteria in Nutrient Broth Containing 3\% $\mathrm{NaCl}$ via Direct and Alternating Electric Currents}

A glass electrolysis cell containing platinum wire electrodes, Nutrient Broth and $3 \% \mathrm{NaCl}$ was utilized in the present study. Two electrodes connected to the following current source presented in Figure 1. During electric current treatments, voltage levels were measured [17], [20].

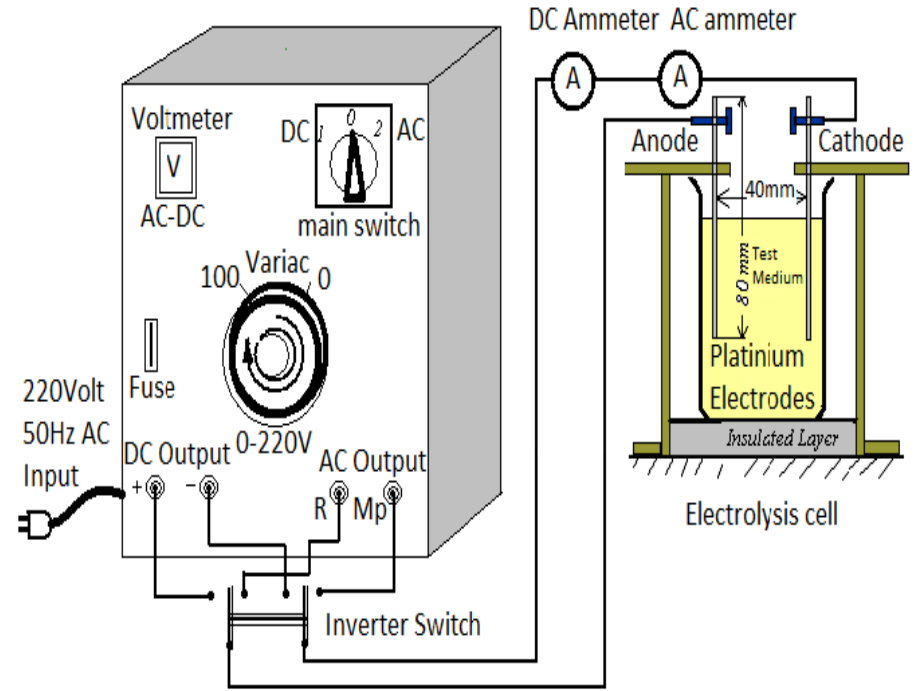

Fig. 1. Electrolysis cell system used in this study, R: phase, Mp: ground.

First, 1A DC was given into the medium for $3 \mathrm{~min}$ and the test medium was left for 3 min without any electric current treatments. Afterwards, 1.5A AC treatment was given into the medium for 3 min and the test medium was left for 3 min without any electric current treatments. This electric treatment was repeated three times. Later, the test medium was left at room temperature for $30 \mathrm{~min}$, and then $1 \mathrm{~A} \mathrm{DC}$ and 1.5A AC treatments applied last time. $100 \mu \mathrm{l}$ of the treated test medium was taken at intervals of $12,24,36$ and 78 min during the DC and AC treatments and these aliquots were diluted to $10^{-2}, 10^{-4}$ and $10^{-6}$ in sterile saline solution to count viable cells. The direct and diluted solutions were spread over NA and incubated at $37^{\circ} \mathrm{C}$ for $24 \mathrm{~h}$ and the colonies on the agar surface were counted. The $\log _{10}$ reduction factor (RF) for each treatment time was calculated [20].

The $\mathrm{pH}$ and temperature values of the test medium were 7.0 and $22^{\circ} \mathrm{C}$ before treatment, respectively. The $\mathrm{pH}$ and temperature values of the test medium during the treatments were measured.

After electric current applications, the test medium was left at room temperature for $10 \mathrm{~h}$, and aliquots of $100 \mu \mathrm{l}$ were taken from the medium after $1 \mathrm{~h}, 2 \mathrm{~h}, 3 \mathrm{~h}, 4 \mathrm{~h}, 5 \mathrm{~h}, 6 \mathrm{~h}, 7 \mathrm{~h}, 8 \mathrm{~h}, 9 \mathrm{~h}$ and $10 \mathrm{~h}$. The aliquots were diluted with sterile saline solution and spread over NA. These plates were incubated at $37^{\circ} \mathrm{C}$ for $24 \mathrm{~h}$ and colonies grown on the agar surface were counted.

\section{Results and Discussion}

Proteolytic and lipolytic test strains were isolated from main soak liquor treated with $0.8 \mathrm{~g} / \mathrm{l}$ of didecyldimethylammonium chloride (quaternary ammonium compound) in our previous study [5]. Bacterial species belonging to the genera Clostridium, Chromobacter, Bacillus, Proteus, Pseudomonas, Serratia, Staphylococcus, Sarcina, Serratia, Micrococcus, Kurthia were isolated from soak liquors in the 
previous studies [1], [34], [35].

In Turkey, duration of main soaking process ranges from 12 hours to 18 hours [3]. Hence, long storage time was preferred in the present study. After four cycles of electric current application, the mixed culture of test strains was left at room temperature for 10 hours (Table 1). Our experiment was accomplished in eleven hours and eighteen minutes.

To reduce rapid temperature increase in hide soak liquors, 1A DC implemented with 1.5A AC was applied four times with a rest break of three minutes after each electric current treatment. Temperature value of the test medium was measured as $34^{\circ} \mathrm{C}$ after the electric current treatments and this value was consisted with the soak liquor temperature in the leather industry [3]. $\log _{10}$ reduction factors of $1.40,1.62,2.00$ and 2.10 belonging to the mixed culture were detected after first, second, third and fourth cycles of electric current treatments, respectively. When the mixed culture damaged by the electric current treatment was stored at room temperature for 10 hours, $1.90 \log _{10}$ reduction factor was detected. Our experiment results showed that bacteria treated by electric current died during the storage periods. At the end of the experiment, the reduction factor of the test bacteria was found as $4.0 \log _{10}$. The voltage levels reduced during the electric treatment (Table 1).

Table 1. Values of Voltage, Temperature and pH, Bacterial Cell Counts (CFU/mL), Reduction Factors (Log10)

\begin{tabular}{|c|c|c|c|c|c|}
\hline $\begin{array}{l}\text { Treatment } \\
\text { time (min) }\end{array}$ & V & ${ }^{\circ} \mathrm{C}$ & $\mathrm{pH}$ & $\begin{array}{c}\mathrm{BCC}^{\mathrm{b}} \\
(\mathrm{CFU} / \mathrm{mL})\end{array}$ & $\begin{array}{c}\mathrm{RFc} \\
\left(\log _{10}\right)\end{array}$ \\
\hline $\mathrm{BE}^{\mathrm{a}}$ & - & 22 & 7.0 & $5.0 \times 10^{7}$ & - \\
\hline 12 & 16.1 & 27 & 7.0 & $2.0 \times 10^{6}$ & 1.40 \\
\hline 12 & 14.0 & 30 & 7.0 & $1.2 \times 10^{6}$ & 1.62 \\
\hline 12 & 12.8 & 33 & 7.0 & $5.0 \times 10^{5}$ & 2.00 \\
\hline \multicolumn{6}{|c|}{ Storage duration (min) } \\
\hline 30 & - & 31 & 7.0 & - & - \\
\hline \multicolumn{6}{|c|}{ Treatment time (min) } \\
\hline 12 & 13.0 & 34 & 7.0 & $4.0 \times 10^{5}$ & 2.10 \\
\hline \multicolumn{6}{|c|}{ Storage duration (hour) } \\
\hline 1 & - & 30 & 7.0 & $8.0 \times 10^{4}$ & 2.80 \\
\hline 2 & - & 26 & 7.0 & $7.0 \times 10^{4}$ & 2.85 \\
\hline 3 & - & 24 & 7.0 & $4.0 \times 10^{4}$ & 3.10 \\
\hline 4 & - & 24 & 7.0 & $2.0 \times 10^{4}$ & 3.40 \\
\hline 5 & - & 24 & 7.0 & $1.4 \times 10^{4}$ & 3.55 \\
\hline 6 & - & 24 & 7.0 & $1.0 \times 10^{4}$ & 3.70 \\
\hline 7 & - & 24 & 7.0 & $7.2 \times 10^{3}$ & 3.84 \\
\hline 8 & - & 24 & 7.0 & $7.0 \times 10^{3}$ & 3.85 \\
\hline 9 & - & 24 & 7.0 & $5.2 \times 10^{3}$ & 3.98 \\
\hline 10 & - & 24 & 7.0 & $5.0 \times 10^{3}$ & 4.00 \\
\hline
\end{tabular}

In another experiment, the mean value of non-halophilic bacteria was found as $10^{5} \mathrm{CFU} / \mathrm{mL}$ and $10^{6}$ $\mathrm{CFU} / \mathrm{mL}$ in first (seven samples) and main (seven samples) soak liquors, respectively. Microorganisms in the first (seven samples) and main (three samples) soak liquors were killed after 20-30 min of 2A direct electric current treatment but microorganisms in the other four main hide-soak liquor samples were killed in $50 \mathrm{~min}$. After $50 \mathrm{~min}$ electric treatment, the mean values of log reduction factors in the first soak and main soak liquors were reported as 5.27 and 6.01, respectively. The temperatures of all soak liquors increased rapidly and reached to $96-98^{\circ} \mathrm{C}$ after 50 min treatment [19].

The researchers examined the effect of $1.5 \mathrm{~A} \mathrm{DC}$ applied together with $2 \mathrm{~A}$ AC treatment on the mixed culture found in liquid medium containing $2 \% \mathrm{NaCl}$ and organic substances, followed by eight hours storage. 
Mixed culture of Gram-negative (Enterobacter cloacae, Vibrio fluvialis and Pseudomonas luteola), Gram-positive (Staphylococcus cohnii and Enterococcus faecium) and Gram-positive endospore forming bacteria (Bacillus pumilus) was used in that study. Investigators firstly applied 1.5 A DC for two min, followed by $2 \mathrm{~A}$ AC treatment for two min on the mixed culture. Then, the treated test medium was left for four min. Later, this current application was repeated three times. After, the medium was left standing at room temperature for eight hours. Reduction factor was detected as $2.32 \log _{10}$ after the three electric current treatments.

Reduction factor of $1.98 \log _{10}$ was obtained after the storage of the test medium. Total reduction factor was mentioned as $4.30 \log _{10}$ at the end of the experiment [29]. Although different bacterial strains except Enterobacter cloacae and different salt concentration were used in that study, the $\log _{10}$ reduction results obtained after the electric current and storage experiments in that study were similar to the results of our study.

Researchers investigated the $\mathrm{pH}$ values of 19 soak liquors obtained from tanneries in Tuzla Leather Organized Industrial Zone in Turkey. The pH values of the soak liquors were measured between 7 to 10 [3]. Hence, the $\mathrm{pH}$ value of our test medium was adjusted to 7.0 and this value did not change during the experiment (Table 1).

The temperature values of the test medium increased during the electric treatment. The temperature values of test medium at the end of first, second, third and fourth cycles were measured as $27^{\circ} \mathrm{C}, 30^{\circ} \mathrm{C}, 33^{\circ} \mathrm{C}$ and $34^{\circ} \mathrm{C}$, respectively. At the end of the experiment, the temperature of test medium was $24^{\circ} \mathrm{C}$ (Table 1 ). Temperature of the soak liquors may change according to tanneries. It was stated that the temperature values of soak liquors in Turkey were between $18-32^{\circ} \mathrm{C}$ [3]. Our temperature values during electric treatments were similar to the temperature values of soak liquors obtained from the tanneries in Turkey.

Researchers isolated Enterobacter cloacae, Enterobacter amnigenus biogrup I, Enterobacter gergoviae, Enterobacter sakazakii, Pseudomonas luteola, Pseudomonas fluorescens, Pseudomonas putida, Pseudomonas aeruginosa, Enterococcus faecium, Enterococcus avium, Aerococcus viridans, Lactococcus lactis ssp. lactis, Kocuria varians, Vibrio parahaemolyticus, Staphylococcus intermedius, Staphylococcus xylosus, Staphylococcus hominis, Staphylococcus capitis, Staphylococcus sciuri, Staphylococcus cohnii ssp. urealyticus, Staphylococcus epidermidis, Staphylococcus haemolyticus, Staphylococcus lugdunensis, Staphylococcus cohnii ssp. cohnii, Staphylococcus warneri and Micrococcus spp. from the main soak liquor containing the antibacterial agent [5]. As seen, our Gram positive and Gram negative test strains were isolated from the soak liquors in the previous studies [5], [34], [35].

Inactivation of different microorganisms in leather industry using electric current was reported in the previous studies. The researchers stated that extremely halophilic archaea found in salt and non-halophilic bacteria in leather processes were killed by electric current treatments [21], [22], [33], [36]-[38]. In the paper of Birbir and Birbir (2006), 0.5A direct electric current killed the mixed culture of protease and lipase positive extremely halophilic archaeal isolates in $10 \mathrm{~min}$ in the test medium containing organic substances and $25 \% \mathrm{NaCl}[20]$.

Akpolat et al. (2014) isolated eleven lipolytic Acinetobacter johnsonii strains from salted skins and identified these strains using molecular methods [30]. These researchers stated that lipolytic moderately halophilic bacterial strain such as Acinetobacter johnsonii might damage skins. This species was resistant to amikacin $(30 \mu \mathrm{g})$, tobramycin $(10 \mu \mathrm{g})$, kanamycin $(30 \mu \mathrm{g})$, streptomycin $(10 \mu \mathrm{g})$, aztreonam $(30 \mu \mathrm{g})$ and gentamicin $(10 \mu \mathrm{g})$ but susceptible to imipenem $(10 \mu \mathrm{g})$, trimethoprim/sulfamethoxazole $(25 \mu \mathrm{g})$ and piperacillin/tazobactam $(110 \mu \mathrm{g})$. The test strains grew in a wide range of salt concentrations $(3-25 \% \mathrm{NaCl})$. The researchers investigated separately lethal effect of both 1A DC and 1A AC on Acinetobacter johnsonii in three different test media containing Nutrient Broth with 3\% $\mathrm{NaCl}$, Nutrient Broth with $25 \% \mathrm{NaCl}$ and only 
$25 \% \mathrm{NaCl}$. According to their experimental results, five, three and one minute of $1 \mathrm{~A}$ direct electric current treatment were enough to kill Acinetobacter johnsonii in the test media containing Nutrient Broth with 3\% $\mathrm{NaCl}$, Nutrient Broth with $25 \% \mathrm{NaCl}$ and only $25 \% \mathrm{NaCl}$, respectively. Ten, five and one minute of $1 \mathrm{~A}$ alternating electric current treatment were enough to annihilate Acinetobacter johnsonii in the treatment media containing Nutrient Broth with $3 \% \mathrm{NaCl}$, Nutrient Broth with $25 \% \mathrm{NaCl}$ and only $25 \% \mathrm{NaCl}$, respectively [30].

In Turkey, salt obtained from Tuz Lake is commonly used in hide and skin preservation. This crude salt may contain extremely halophilic archaea and these archaeal populations may decrease the leather quality. Hence, Birbir et al. (2014) examined extremely halophilic archaeal populations in five salt samples collected from Tuz Lake. The researchers dissolved the salt samples in brine solutions and applied 2A AC for 25 min. They reported that $2 \mathrm{~A}$ alternating electric current for $1 \mathrm{~min}$ was enough to kill extremely halophilic archaea, proteolytic extremely halophilic archaea and lipolytic extremely halophilic archaea found in salt samples [31].

In the study of Birbir et al. (2015), the mixed culture of five antibiotic resistant, proteolytic and lipolytic moderately halophilic strains (Chromohalobacter israelensis, Halomonas halmophila, Chromohalobacter canadensis, Staphylococcus nepalensis and Halomonas halodenitrificans), isolated from salted skins, was killed via direct and alternating electric currents. The mixed culture was killed in 1, 3, 5, 10 min via 2A DC, 1.5A DC, $2 \mathrm{~A} \mathrm{AC}$ and $1.5 \mathrm{~A} \mathrm{AC}$, respectively. All strains were resistant to bacitracin (0.04 U), pefloxacin (5 $\mu \mathrm{g})$, ofloxacin (5 $\mu \mathrm{g})$, oleandomycin $(15 \mu \mathrm{g})$ and tetracycline $(30 \mu \mathrm{g})$ [32].

In conclusion, $1 \mathrm{~A}$ DC treatment implemented together with $1.5 \mathrm{~A} \mathrm{AC}$ in a sequential manner on mixed culture of proteolytic and lipolytic Gram-positive and Gram-negative hide bacteria in Nutrient Broth containing 3\% $\mathrm{NaCl}$ was effective in killing hide bacteria in hide soak liquors. Hence, we suggest using this treatment system to prevent bacterial damage on hides during hide soaking process.

\section{References}

[1] Rangarajan, R., Didato, T. D., \& Bryant, S. (2003). Measurement of bacterial populations in typical tannery soak solutions by traditional and new approaches. Journal of the American Leather Chemists Association, 477-485.

[2] Berber, D., \& Birbir, M. (2010). Examination of bacterial populations in salt, salted hides, soaked hides and soak liquors. Journal of the American Leather Chemists Association, 320-326.

[3] Berber, D. (2009). Examination of bacterial population in salt, salted and soaked raw hides. PhD thesis, Institute of Pure and Applied Sciences, Marmara University.

[4] Lefebvre, O., Vasudevan, N., Torrijos, M., \& Moletta, R. (2005). Halophilic biological treatment of tannery soak liquor in a sequencing batch reactor. Water Research, 1471-1480.

[5] Berber, D., Birbir, M., \& Hacioglu, H. (2010). Efficacy assesment of bactericide containing didecyldimethylammonium chloride on bacteria found in soak liquor at different exposure times. Journal of the American Leather Chemists Association, 354-359.

[6] John, G. (1997). Possible defects in leather production. Definitions, Causes, Consequences, Remedies and Types of Leather, Druck Partner Rübelmann GmbH, Carl-Benz-Strasse 11, D-69495 Hemsbach, 33-35.

[7] Yapici, A. N. (2008). The effect of using a fungicide along with bactericide in the main soaking float on microbial load. African Journal of Biotechnology, 3922-3926.

[8] Anderson, A. K., \& Finkelstein, R. (1919). A study of the electropure process of treating milk. Journal of Dairy Scence, 374-406.

[9] Beattie, J. M., \& Lewis, F. C. (1925). The electric current (apart from the heat generated). A bacteriological agent in the sterilization of milk and other fluids. Journal of Hygiene, 123-127. 
[10] Prescott, S. C. (1927).The treatment of milk by an electrical method. American Journal of Public Health, 221-223.

[11] Davis, C. P., Wagle, N., Anderson, M. D., \& Warren, M. M. (1991). Bacterial and fungal killing by iontophoresis with long-lived electrodes. Antimicrobial Agents and Chemotherapy, 2131-2134.

[12] Matsunaga, T., Nakasono, S., Takamuku, T., Burgess, J. G., Nakamura, N., \& Sode, K. (1992). Disinfection of drinking water by using a novel electrochemical reactor employing carbon-cloth electrodes. Applied and Environmental Microbiology, 686-689.

[13] Pareilleux, G., \& Sicard, N. (1970). Lethal effects of electric current on Escherichia coli. Applied Microbiology, 421-424.

[14] Bolton, L., Foleno, B., Means, B., \& Petrucelli, S. (1980). Direct-current bactericidal effect on intact skin. Antimicrobial Agents and Chemotherapy, 137-141.

[15] Liu, W. K., Brown, M. R., \& Elliott, T. S. (1997). Mechanisms of the bactericidal activity of low amperage electric current (DC). Antimicrobial Agents and Chemotherapy, 687-695.

[16] Li, X. G., Cao, H. B., Wu, J. C., \& Yu, K. T. (2001). Inhibition of the metabolism of nitrifying bacteria by direct electric current. Biotechnology Letters, 705-709.

[17] Park, J. C., Lee, M. S., Lee, D. H., Park, B. J., Han, D. W., Uzawa, M., \& Takatori, K. (2003). Inactivation of bacteria in seawater by low-amperage electric current. Applied and Environmental Microbiology, 69(4), 2405-2408.

[18] Ye, I., Yang, H., Kim, H. K., \& Li, Y. (2001). Inactivation of Listeria monocytogenes in recirculated brine for chilling thermally processed bacon using an electrochemical treatment system. Journal of Food Science, 729-733.

[19] Birbir, Y., Ugur, G., \& Birbir, M. (2008). Inactivation of bacterial population in hide soak liquors via direct electric current. Journal of Electrostatics, 355-360.

[20] Birbir, Y., \& Birbir, M. (2006). Inactivation of extremely halophilic hide-damaging bacteria via low-level direct electric current. Journal of Electrostatics, 791-795.

[21] Birbir, Y., Degirmenci, D., \& Birbir, M. (2008) Direct electric current utilization in destruction of extremely halophilic bacteria in salt which is used in brine curing of hide. Journal of Electrostatics, 388-394.

[22] Birbir, M., Özdogru, B., Birbir, Y., \& Ogan, A. (2008). Extracellular protease activities of extremely halophilic archaea and their control via direct electric current. Journal of the Society of Leather Technologists and Chemists, 92(2), 53-58.

[23] Birbir, M., Hacioglu, H., \& Birbir, Y. (2009). Inactivation of Escherichia coli by alternative electric current in rivers discharged into sea. Journal of Electrostatics, 67(4), 640-645.

[24] Mahapatra, A. K., Harris, D. L., Neguyen, C. N., \& Kannan, G. (2011). Reduction of E. coli 0157:H7 on beef surfaces using low-voltage direct electric current and the impact on sensory properties. Journal of Electrostatics, 30-35.

[25] Slavik, M. F., Griffis, C., Li, Y., \& Engler, P. (1991). Effect of electrical stimulation on bacterial contamination of chicken legs. Journal of Food Protection, 508-513.

[26] Sale, A. J. H., \& Hamilton, W. A. (1967). Effects of high electric fields on microorganisms: killing of bacteria and yeasts. Biochimica et Biophysica Acta, 781-788.

[27] Van der Borden, A. J., Van der Mei, H. C., \& Busscher, H. J. (2004). Electric current induced detachment of Staphylococcus epidermidis strains from surgical stainless steel. Journal of Biomedical Materials Research, 160-164.

[28] Liu, W. K., Tebbs, S. E., Byrne, P. O., \& Elliot, T. S. (1993). The effects of electric current on bacteria colonizing intravenous catheter. Journal of Infection, 261-269. 
[29] Birbir, Y., Dölek, N., Birbir, M., \& Caglayan, P. (2013). Synergistic effect of direct and alternating electric current treatments and bronopol to inactive bacteria found in hide soak liquors. Journal of the American Leather Chemists Association, 108(10), 373-385.

[30] Akpolat, C., Birbir, Y., Birbir, M., Ventosa, A., Caglayan, P., \& Sánchez-Porro, C. (2014). Characterization and electrochemical inactivation of antibiotic-resistant Acinetobacter johnsonii isolated from salted sheep skins. Proceedings of the 4th International Meeting On Pharmacy \& Pharmaceutical Sciences, 18-21 September, Istanbul-Turkey, Abstract Book, (p. 77).

[31] Birbir, Y., Anik, S., Birbir, M., \& Caglayan, P. (2014). Destruction of extremely halophilic archaea via alternating electric current. Proceedings of the 5th International Symposium on Sustainable Development [ISSD 2014] (p. 157).

[32] Birbir, Y., Caglayan, P., Birbir, M., Ogan, A., Ventosa, A., \& Sánchez-Porro, C. (2015). Controlling antibiotic-resistant moderately halophilic bacteria via direct and alternating electric currents. Proceedings of International Leather Engineering Congress, Innovative Aspects for Leather Industry (p. 133).

[33] Aslan, E., \& Birbir, M. (2011). Examination of gram-positive bacteria on salt-pack cured hides. Journal of the American Leather Chemists Association, 372-380.

[34] Birbir, M., \& Ilgaz, A. (1996). Isolation and identification of bacteria adversely affecting hide and leather quality. Journal of the Society of Leather Technologists and Chemists, 147-153.

[35] Pfleiderer, E., \& Reiner, R. (1988). Microorganisms in processing of leather in biotechnology. Biotechnology, 729-743.

[36] Birbir, Y., Molla, S., \& Birbir, M. (2013b). Applying electric current to inactivate Gram-negative bacteria isolated from salt-packed-cured hides. Journal of the Society of Leather Technologists and Chemists, 5-10.

[37] Birbir, Y., Dölek, N., \& Birbir, M. (2013c). Effect of a combined treatment using both direct and alternating electric currents on hide bacteria in hide-soak liquor. Journal of Electrostatics, 898-904.

[38] Birbir, Y., Dölek, N., \& Birbir, M. (2014). Treatment using both direct and alternating electric currents on hide bacteria in brine curing and pre-soaking liquors. Journal of the Society of Leather Technologists and Chemists, 47-55.

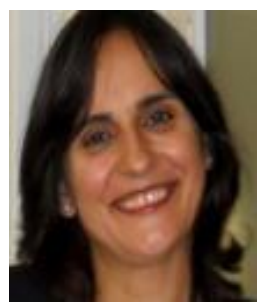

Meral Birbir received a bachelor's degree in biology education in 1985, the M.Sc. and PhD. degrees in 1987 and 1991, respectively from the Department of Biology, Marmara University. She has been working at Biology Department of Marmara University since 1985. She was a visiting research scientist in Department of Pathology and Microbiology, Veterinary Medical School, Purdue University in 1990. She was a research scientist in Hides and Leather Department of USDA from 1992 to 1993. She was Erasmus Coordinator of Biology Department, Marmara University between 2006 and 2015.

She teaches undergraduate and graduate courses in biology, microbiology, clinic microbiology and industrial microbiology. Her research interests are halophilic bacteria, hide microbiology, food microbiology, antimicrobial agents, electric current application and microbiology of hypersaline environment. Professor Birbir especially focused on halophilic and non-halophilic bacteria that live on salted hides and their control with antimicrobials or electric current. She has published 62 research articles and graduated 30 masters and two doctorate students. She presented 69 oral or poster presentations in national and international congresses. She has completed 33 scientific projects. 


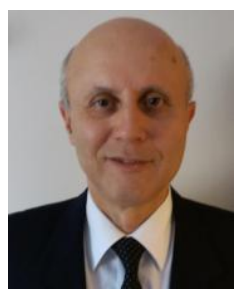

Yasar Birbir received the B.S degree from Gazi University, the M.Sc. and PhD. from Marmara University. He attended World Bank Industrial Training Project at Indiana and Purdue Universities from 1989 to 1990. He had worked as a visiting research scientist for fifteen months at Drexel University Electrical and Computer Engineering Department from 1992 to 1993. Currently he has been working as a Professor at Technology Faculty in Department of Electrical Engineering.

He teaches undergraduate and graduate courses in power electronics courses and electrical machinery drives. His current interests are power electronic converters, drivers, electromagnetic filtering process in the industry. In addition, the applications of electric currents and electric field to inactivate different microorganisms are his research subjects. He has published 20 research articles and graduated 12 masters and two doctorate students. He presented 33 oral or poster presentations in national and international congress. He has completed 8 scientific projects.

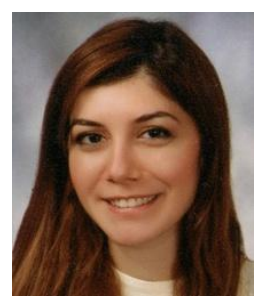

Esin Yilmaz graduated from Department of Biology, Ataturk Faculty of Education, Marmara University, Turkey in 2011. She is master student (M.Sc.) in biology from Institute for Graduate Studies in Pure and Applied Science, Marmara University. She has been working as a biology teacher in private high school. Her research experience is controlling growth of bacteria using electric current applications.

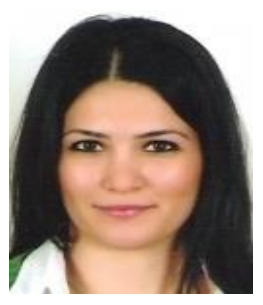

Pinar Caglayan graduated from Department of Biology, Ataturk Faculty of Education, Marmara University, Turkey in 2007. She received her M.Sc. degree in biology in 2010 from Institute of Pure and Applied Sciences, Marmara University. She was an Erasmus student in Department of Microbiology and Parasitology, Faculty of Pharmacy, Sevilla University, Spain from 2008 to 2009 and 2013. Pinar Caglayan received her PhD. degree at Marmara University, Department of Biology in 2015.

She has been working as a research and teaching assistant of the Division of Plant Diseases and Microbiology, Department of Biology, Faculty of Science and Letters, Marmara University since 2011. Her research interests are moderately halophilic bacteria, extremely halophilic Archaea, antimicrobial agents, electric currents and hide microbiology. She has published 9 research articles. She presented 33 oral or poster presentations in international and national congresses. She has completed one scientific project as a researcher at Marmara University. 